\title{
PERLINDUNGAN HUKUM PEKERJA DALAM PERJANJIAN KERJA SECARA LISAN DALAM PERSELISIHAN MENGENAI UPAH
}

\author{
Oleh : \\ Mashudi*, Happy Trizna Wijaya**, Adi Putra Sion Dakawetang**** \\ *Fakultas Hukum, Universitas Gresik \\ Email : mashudiunigres@ gmail.com \\ **Fakultas Hukum, Universitas Gresik \\ Email : Bebek_Cepat@yahoo.co.id \\ ***Fakultas Hukum Universitas Gresik \\ Email: Adiputrasion94@gmail.com
}

\begin{abstract}
ABSTRAK
Dalam Penelitian ini penulis meneliti tentang perlindungan hukum pekerja dalam perjanjian kerja secara lisan dalam perselisihan mengenai upah. Hal ini dilatar belakangi karena upah merupakan hak normatif bagi pekerja. Perselisihan hubungan industrial adalah pendapat yang berbeda yang mengakibatkan pertentangan antara pengusaha dan pekerja karena adanya perselisihan hak seseorang. Hasil penelitian ini menunjukkan bahwa Perlindungan Pekerja dalam kegiatannya memiliki hak dan kewajiban dimana kewajiban pekerja adalah bekerja sesuai dengan aturan baik aturan hukum serta aturan kerja, sedangkan hak pekerja adalah menerima uang atas pekerjaannya yang telah dilakukan disaat bekerja.
\end{abstract}

Kata Kunci: Hak; Upah;Upaya Hukum; Perlindungan; Pekerja.

\section{A. PENDAHULUAN}

\section{A. Latar Belakang}

Dalam melaksanakan suatu pembangunan di negara indonesia sekarang yang selalu dititik beratkan pada pembangunan dalam dibidang ekonomi, hukum ialah mempunyai fungsi yang sangat penting dalam menunjang kemajuan perekonomian di Indonesia. Dalam melaksanakan pembangunan dengan tekanan yang lebih menonjol.

Untuk mengabulkan keinginan masyarakat faktor tenaga kerja harus di perhatikan. Mulai pembinaan pengarahan dan perlindungan tenaga kerja. Semata-mata untuk menciptakan proses pembangunan dan kesejahteraan. Ditambah dengan total warga yang sangat banyak, itu membentuk salah satu cara yang amat penting.

Dalam membicarakan perkembangan hukum tentang pekerja khususnya di indonesia, uraian mengenai pertumbuhan dan perkembangannya tidak semata-mata dari Undang-Undang dan peraturan lainnya mengenai ketenagakerjaan (tenaga kerja). Hukum ketenagakerjaan yang ada pada masa itu adalah hukum ketenagakerjaan asli indonesia. ${ }^{1}$

Hukum ketenagakerjaan adat yang lantaran sifatnya tidak tertulis, maka perkembangan susah diuraikan bersama penandaan tahun atau bulan. Pada bukti pada sebelum pemerintah Hindia Belanda, telah ada orang yang mempunyai budak. Aturan perundang-undangan yang ada dari zaman Hindia Belanda mencapai era reformasi masa ini sebenarnya sudah menyiapkan perangkat hukum yang mengontrol mengenai kemungkinan menuju kehidupan ketenagakerjaan yang serasi dan seimbang. Jumlah tenaga kerja yang tersedia di Indonesia tidak seimbang dengan jumlah lapangan kerja yang tersedia. Terlebih lagi dari sebagian besar tenaga kerja yang tersedia adalah yang berpendidikan rendah atau tidak berpendidikan sama sekali. Mereka kebanyakan adalah

\footnotetext{
${ }^{1}$ Suratman, Pengantar Hukum Ketenagakerjaan Indonesia, RajaGrafindoPersada, Depok, h. 21.
} 
unskilllabour, sehingga posisi tawar mereka menjadi rendah. ${ }^{2}$

Tentu saja setiap manusia menjadi tergantung terhadap pekerjaan itu. Bahkan bisa disebut pula dapat terjadinya salah satu tolak ukur kesuksesan seorang pekerja dalam hidupnya terutama dibidang ekonomi.

Setiap orang memiliki keinginan atau cita-cita di dalam hidup ini . tidak ada orang yang pasrah saja menerima nasib atau tanpa berbuat apa-apa atas kondisi yang menimpanya, khususnya jika kondisi itu kurang menguntungkan dalam hidupnya.

Kebutuhan yang tidak cukup dapat mengakibat kemiskinan dan masalah dalam kehidupan seseorang. Yang di sebabkan kurang memiliki etos kerja tinggi atau etos kerjanya rendah, adanya faktor lain yang mempengaruhinya, rendahnya etos kerja inilah yang mengakibatkan sulitnya kehidupan rakyat bisa berubah menjadi lebih baik.

Dalam kehidupan seseorang, cita-cita kita dalam bernegara adalah untuk mewujudkan bangsa yang seimbang. Dapat mewujudkan citacita mulia itu bahwa kita butuh melaksanakan pembangunan. kita sebagai masyarakat akan bisa meningkatkan kemakmuran.Hal itu menunjukan bahwa dalam hidup ini seseorang membutuhkan pekerjaan. Dengan pekerjaan yang dilaksanakan manusia dapat memenuhi berbagai kebutuhan hidupnya. Sebab dari pekerjaan yang di lakukan itu manusia mendapatkan penghasilan. Manusia mempunyai haknya sebagai mana pekerjaan dapat menentukan penghasilan. Sedangkan penghasilan ini juga menjadi hak yang harus dimilikinya setelah menjalankan pekerjaan.

Pembahasan ini yang berhubungan dengan hukum termasuk hukum ketenagakerjaan memegang peranan penting. Jika dikaitkan dengan para pekerja yang selama ini menjadi sorotan dikalangan pengamat, yang menyangkut nasib para pekerja di tengah kehidupan ekonomi yang tidak stabil. ${ }^{3}$

Sementara itu para pekerja menuntut kenaikan upah yang layak menuntut di jadikan karyawan tetap, menuntut tunjangan. Sementara pengusaha menghadapi situasi bisnis yang tidak menentu

\footnotetext{
${ }^{2}$ Asri Wijayanti, Hukum Ketenagakerjaan Pasca Reformasi, Cet. VI,Sinar Grafika, Jakarta, 2016, h. 75. ${ }^{3}$ Joni Bambang, Hukum Ketenagakerjaan, Cet. I, CV Pustaka Setia, Bandung, 2013, h. 15.
}

disebabkan kenaikan biaya produksi dan sebagainya. Dilema itu menjadi bagian penting dari lahirnya peraturan ketenagakerjaan yang menghendaki keseimbangan perlakuan yuridis untuk pekerja dan pemberi kerja sehingga dapat terciptanya kesejahteraan dan keadilan yang rasional.

Pekerja sangat membutuh perlindungan dalam mendapatkan haknya bahwa posisi pekerja sangatlah lemah maka dibentuknya serikat pekerja yang berada di perusahaan. Ada suatu perkataan dalam serikat pekerja belum menjadi suara pekerja baik di tingkat kerja.

Secara yuridis normatif jaminan perlindungan hak-hak telah diatur dalam peraturan perundang-undangan maupun peraturan pelaksana. Namun demikian masalah perlindungan hak-hak pekerja masih selalu menimbulkan persoalan. Persoalan tersebut bersumber baik dari kelemahan peraturan perundang-perundangan. ${ }^{4}$

Pada umunya masing-masing perusahaan pasti melaksanakan masa percobaan bagi para calon pekerja (magang) sebelum diterima menjadi pekerja dalam arti sebelum mengadakan perjanjian kerja. Pada waktu saat percobaaan yang dimaksudkan untuk memfokuskan peserta. bagaimanakah mampu atau tidak untuk melaksanakan pekerjaan yang mau di serahkan untuknya serta untuk memahami kepribadian calon pekerja (magang). Seandainya menurut penilaian majikan calon pekerja (magang) layak untuk dipekerjakan, maka majikan membawa calon pekerja (magang) sebagai pekerja dengan aturan dibuatnya perjanjian kerja.

Untuk membuat perjanjian kerja biasanya di dahului oleh masa yang harus di lalui sebelum adanya perjanjian kerja yang disebut masa percobaan. Dengan demikian ada perjanjian kerja yang di dahului dengan masa percobaan dan ada perjanjian kerja tanpa di dahului dengan masa percobaan.

\section{B. Metode Penelitian}

Penelitian yang digunakan dalam menganalisa dan mengembangkan permasalahan dalam penelitian ini adalah termasuk jenis penelitian hukum normatif. Penelitian hukum normatif adalah penelitian hukum untuk menemukan

\footnotetext{
${ }^{4}$ Ikhwan Fahrojih, Hukum Perburuhan, Setara Press, ,Cet. I, Malang, 2016, h. 29.
} 
aturan hukum, prinsip-prinsip hukum, maupun doktrin-doktrin hukum guna menjawab isu hukum (legal issue) yang ada, sehingga peneliti mendapatkan gambaran yang jelas tentang masalah yang diteliti dalam penelitian ini dan peneliti dapat menyimpulkan pada penelitian hukum normatif mempunyai cakupan yang luas.

a. Bahan hukum tersier yang dimaksud dalam penulisan skripsi ini yaitu bahan hukum yang memberikan pengarahan atau sebuah petunjuk terhadap bahan hukum primer dan sekunder. Bahan hukum yang digunakan dalam penelitian ini berupa kamus hukum, ensiklopedia, dan bahan-bahan penunjang kelengkapan bahan- bahan hukum primer dan sekunder yang relevan dengan permasalahannya.

\section{Pembahasan}

\section{A. Sejarah Hukum Pekerja}

Histori hukum ketenagakerjaan secara jelasnya yang ada di Indonesia pasca reformasi. Atas waktu itu terdapat empat waktu pemerintahan yakni masa pemerintahan Baharudin Jusuf Habibie, semasa pemerintah Abdurrahman Wahid, semasa pemerintahan Megawati, dan semasa pemerintahan Susilo Bambang Yudhoyono.

Munculnya hukum pekerja pertama kali ditengarai berlangsung di eropa akibat terjadinya revolusi industri di inggris. Sebagian besar pekerja kasar tidak dapat lagi menikmati cara hidup tradisional yang berbasis agrikultur karena semakin sempitnya peluang sehingga meningkatkan taraf kemiskinan karena itu mereka terpaksa mencari pekerjaan sebagai buruh pabrik.

Pekerja terpaksa menerima kondisi kerja yang ditetapkan oleh perusahaan yang jumlahnya terbatas tersebut. Kemiskinan memaksa seseorang termasuk anak-anak kecil bekerja dalam waktu yang sangat panjang dengan kondisi kerja yang mengancam kesehatan dan keselamatan mereka terutama pabrik.

Upaya pemerintah untuk memberikan perlindungan pada kesehatan dan keselamatan kerja melalui hukum tidak berjalan dengan mulus. Karena saat berlangsung revolusi industri konsep negara hukum yang berkembang adalah negara hukum liberal atau negara hukum klasik dengan doktrin laissez-faire.
Pada era inilah hukum pekerja hanya dianggap sebagai hubungan keperdataan antara dua belah pihak berdasarkan pilihan bebas masing-masing pihak. Kondisi ini penindasan karena pekerja selalu berposisi subordinat terhadap pemberi kerja.

Berdasarkan pemikiran di atas tersebut maka hukum pekerja bukan hanya sekedar hubungan kerja saja melainkan antara pemberi kerja dan pekerja, melainkan itu negara juga ikut hadir untuk mengatur dan menegakan aturan tentang jaminan hukum perlindungan hak-hak buruh.

Napoleon menyebarkan ide baru tentang hukum tersebut ke seluruh benua eropa. Meskipun demikian selama kurun abad ke 19 tampaknya kebebasan-kebebasan baru tersebut hanya dapat di nikmati sekelompokDari ketentuan tersebut, dapat dikatakan bahwa masa percobaan kerja boleh diadakan atau boleh tidak diadakan. Selain itu berarti masa percobaan pekerja berwenang atas upah. kecil masyakarat elite yang muncul kemudian. ${ }^{5}$

Pembangunan nasional khususnya bidang ketenagakerjaan diarahkan untuk sebesarbesarnya bagi kemakmuran dan kesejahteraan masyarakat pekerja. Oleh karena itu hukum ketenagakerjaan harus dapat menjamin kepastian hukum, nilai keadilan, asas kemanfaatan, ketertiban, perlindungan dan penegakan hukum. Seiring dengan pembangunan bidang ketenagakerjaan tampaknya para pelaku yaitu pemberi kerja berbenah diri pasca krisis ekonomi dan moneter untuk bangun dari mimpi buruk serta terpaan gelombang krisis ekonomi global yang melanda asia tenggara di mana indonesia tidak terlepas dari gelombang tersebut.

Pemerintah dalam upaya mengatasi krisis ekonomi global bersama dengan masyarakat terutama pemberi kerja salah satu alasan pokok untuk menstabilkan perekonomian dan menjaga keseimbangan moneter serta menghindari kebangkrutan sebagian besar perusahaan yang berdampak terhadap sebagian besar nasib para pekerja pabrikan dan berujung pada pemutusan hubungan kerja.

Pekerja merupakan salah satu aspek yang sangat berpengaruh terhadap semua perkembangan perekonomian di indonesia. Pekerja juga tidak terlepas dari kehidupan dan pekerja juga merupakan togak utama perekonomian suatu

\footnotetext{
${ }^{5}$ Joni Bambang, Op.Cit., h.51.
} 
bangsa indonesia, disamping sumber daya alam dan teknologi. Bahkan di negara-negara berkembang pada umumnya memiliki tingkat pengangguran yang jauh lebih tinggi dan angka resmi yang dikeluarkan pemerintah.

\section{B. Perjanjian Kerja}

Perjanjian adalah hal yang dimana seorang bersama orang lain untuk melakukan perjanjian untuk melakukan hal yang mereka perjanjiankan. Apabila dibandingkan perikatan dengan perjanjian maka selain perjanjian merupakan sumber perikatan selain Undang-Undang, perikatan juga merupakan pengertian yang masih abstrak karena pihak-pihak dikatakan melaksanakan sesuatu hal akan tetapi dalam perjanjian itu adalah sesuatu pengertian yang konkret.

\section{Perjanjian Kerja Bersama}

PKB ialah perjanjian yang dapat menghasilkan perundingan kepada serikat pekerja, pekerja yang tercantum pada badan yang berkewajiban bagian ketenagakerjaan bersama pengusaha atau pengumpulan pengusaha yang membawa persyaratan kerja dengan hak dan kewajiban kepada dua pihak tersebut.

Proses langkah untuk melakukan PKB dilakukan selaku musyawarah antara untuk pihak yang berunding. Bilamana musyawarah tidak mememperoleh kesepakatan tentang suatu hal bahwa penyelesaiannya dilakukan melalui prosedur PPHI. PKB wajib dibuat dalam bentuk tercatat atas huruf latin (indonesia).

\section{Macam dan Mekanisme Penyelesaian Perselisihan Hubungan Industrial Diluar Pengadilan}

Lahirnya Undang-Undang Nomer 2 Tahun 2004 tentang PPHI membentuk sesuatu yang penting dalam kerangka PPHI. Dapat dibilang sesuatu yang amat penting karena melalui perundang-undang muncullah yang namanya lembaga peradilan dapat mengadili, memeriksa, menangani dan memutuskan PPHI.

Sebelum berlakunya UU Nomer 2 Tahun 2004 tentang PPHI dilakukan dengan berdasarkan pada UU Nomer 22 Tahun 1957 Tentang Penyelesaian Perselisihan Perburuan.

UU Nomer 22 Tahun 1957 yang sudah dari dulu dipergunakan menjadi aturan hukum PPHI menduga tidak dapat lagi membantu karena hakhak pekerja belum terbiasa untuk sebagai pihak dalam PPHI.

\section{E. Upaya Penyelesaian Perselisihan Bipartit}

Penyelesaian melalui Bipartit merupakan suatu langkah pertama sesorang yang wajib dilaksanakan dalam penyelesaian sengketa tenaga kerja oleh pengusaha, pekerja maupun serikat pekerja menjadi langkah upaya menyelesaian PPHI secara pembicaraan untuk mufakat.

Upaya melalui bipartit adalah menyelesaikan secara kekeluargaan dengan cara berkompromi secara pembicaraan kira-kira para pihak yang mengalami sengketa terutama dalam terjadinya perselisihan hak celah pekerja dan pengusaha untuk menemukan jalan tengah yakni solusi yang dapat memberikan keuntungan bagi pihak yang mengalami sengketa. Tenggang waktu dalam penyelesaian menurut bipartit dilakukan dalam waktu 30 hari tanpa adanya perpanjangan jangka waktu.

\section{F. Upaya Penyelesaian Perselisihan Melalui Hukum Mediasi}

Agar bisa melakukan mediasi kepada pihak harus menemukan kata sepakat agar berdamai,penyelesaian sebuah permasalahan yang sama-sama menguntungkan kepada pihak sehingga para pihak yang bersengketa tidak perlu melanjutkan sengketa melalui lembaga peradilan khususnya Pengadilan Hubungan Industrial.

Sebagaimana mediator pada Pasal 15 UU Republik Indonesia Nomer 2 Tahun 2004, wajib untuk menyelesaikan tugasnya dalam batas selambat-lambatnya 30 hari kerja terhitung semenjak menerima pelimpahan penyelesaian perselisihan. Maka waktu tenggang yang dibutuhkan akan menyelesaikan perselisihan dalam upaya mediasi adalah paling lambat 30 hari rodi. Usaha yang dilaku mediasi diharapkan dalam keadaan tersebut agar tidak menghabiskan batas yang lama yakni melebihi 30 hari rodi.

\section{Penutup}

\section{A. Kesimpulan}

Perlindungan Pekerja dalam kegiatannya memiliki kewajiban pekerja ialah bekerja sesuai dengan aturan baik aturan hukum serta aturan dari perusahaan ditempat mereka bekerja, sedangkan hak pekerja adalah menerima upah atas pekerjaan yang telah dilaksanakannya. Maka hak dan kewajiban harus dijalankan secara seimbang, maka tidak dapat dibenakan jika pekerja menuntut hak dan kewajibannya tidak bisa dilaksanakan, begitu juga sebalikanya tidak dapat dibenarkan apabila pekerja telah melaksanakan kewajibannya namun tidak 
mendapatkan haknya maka pemerintah menjamin kesejahteraan pekerja dengan membentuk peraturan-peraturan terkait seperti peraturan perundang-undangan ketenagakerjaan serta peraturan pelaksananya seperti peraturan tentang pengupahan dan peraturan mengenai upah minimum pekerja.

Upaya hukum dalam hal terjadi perselisihan terhadap hak terkait upah dapat ditempuh pekerja dimulai dari upaya hukum di luar pengadilan dengan cara menyelesaikan perselisihan secara kekeluargaan atau pihakpihak yang melakukan perselisihan hingga proses penyelesaian melalui Pengadilan Negeri setempat.

\section{Saran}

a. Perekonomian yang di alami Indonesia dari dulu sampai sekarang selalu tiap tahunnya berubah-ubah, akan dapat menjadi suatu perubahan perekonomian yang dikhawatirkan akan mempengaruhi masyarakat dalam memenuhi kebutuhan hidupnya. Diharapkan pemerintah memperhatikan kemakmuran masyarakatnya dari salah satunya dengan cara menjamin hak pekerja dalam mendapatkan upahnya karena upah yang didapatkan ini yang digunakan oleh pekerja dalam memenuhi kebutuhan hidupnya.

b. Para pihak yang berselisih hendaknya dapat menghadiri panggilan sidang mediasi dan dapat menyediakan data-data yang terkait dengan perselisihan secara cepat, sehingga tidak menghambat jalannya proses mediasi. Para pihak yang tidak mengalami perselisihan hendaknya tidak mencampuri suasana dengan perkataan yang menghasut kepada mediator.

\section{Daftar Bacaan}

Buku-buku

Bambang, Joni, "Hukum Ketenagakerjaan", Cet. I,CV Pustaka Setia, 2013.

Fahrojih, Ikhwan, "Hukum Perburuhan", Cet. I,Setara Press, Malang, 2016.

Mahmud Marzuki, Peter, "Penelitian Hukum", Cet. VIII, Kencana Prenada Media Group, Jakarta, 2010.

Suratman, "Pengantar Hukum Ketenagakerjaan indonesia", Cet. I, PT RajaGrafindo Persada, Depok, 2019.

Wijayanti, Asri, "Hukum Ketenagakerjaan Pasca Reformasi", Cet. VI, Sinar Grafika, Jakarta, 2016. 